\title{
FLUORESCENCE ANALYSIS, PHYTOCHEMICAL AND ANTIOXIDANT ACTIVITIES IN LEAVES AND STEM OF EMBELIA RIBES BURM. F
}

\author{
VIDYA KAMBLE, NIKHIL GAIKWAD* \\ Department of Botany, Shivaji University, Kolhapur, Maharashtra, India. Email: nbgaikwadsuk@gmail.com
}

Received: Received: 07 December 2018, Revised and Accepted: 13 March 2019

\begin{abstract}
Objective: The objective of the present study is to carry out fluorescence analysis, phytochemical, and antioxidant activities using different solvent extract in leaves and stem of Embelia ribes.

Methods: In the present study, fluorescence analysis, phytochemical, and antioxidant activities of leaves and stem of E. ribes are carried out using standard procedures.

Result: The fluorescence analysis under visible and ultraviolet light for leaves and stem powder of $E$. ribes treated with various chemical reagents shown different fluorescence effect. In the phytochemical analysis, the methanolic extract of leaves has shown the highest total alkaloid content $(19.05 \pm 0.42 \mathrm{mg}$ $\mathrm{CE} / \mathrm{g} \mathrm{DW}$ ), followed by the stem. The methanolic extract of stem exhibited highest total phenolic content (59.82 $\pm 2.98 \mathrm{mg}$ GAE/g DW), and ethanolic extract showed highest total flavonoid content $(10.05 \pm 0.36 \mathrm{mg}$ RE/g DW), followed by leaves. The ethanolic extract of stem possesses highest antioxidant activity toward 1,1-diphenyl-2-picrylhydrazyl (DPPH) (84.86 $\pm 0.11 \%)$, whereas methanolic extract of stem reported highest Ferric reducing antioxidant power (FRAP) activity (72.22 $\pm 0.31 \mathrm{mg} \mathrm{Fe+2E/g} \mathrm{DW),} \mathrm{followed} \mathrm{by} \mathrm{leaves.} \mathrm{Antioxidant} \mathrm{activities} \mathrm{(DPPH} \mathrm{and} \mathrm{FRAP)} \mathrm{were} \mathrm{significantly} \mathrm{correlated} \mathrm{with} \mathrm{TPC.}$
\end{abstract}

Conclusion: The results of the present study revealed that the fluorescence analysis of leaves and stem of $E$. ribes can be helpful for the standardization and quality control of indigenous drug. Both leaves and stem serve as the good source of secondary metabolite and antioxidant agents.

Keywords: Embelia ribes, fluorescence analysis, antioxidant, alkaloids, phenol, flavonoid.

(C) 2019 The Authors. Published by Innovare Academic Sciences Pvt Ltd. This is an open access article under the CC BY license (http://creativecommons. org/licenses/by/4. 0/) DOI: http://dx.doi.org/10.22159/ajpcr.2019.v12i4.30782

\section{INTRODUCTION}

Medicinal plants have been used as resourceful medium in traditional medicinal system from primitive period. The potentiality of plant depends on the presence of phytochemicals such as amino acids, proteins, alkaloids, phenols, flavonoids, and tannins. At present, about $75 \%$ of population depends on the traditional system of medicine for the treatment of various diseases [1]. Plant-based chemical substances show very minor side effect and serve as the best curative materials. Medicinal plants, during development, produce a variety of secondary metabolites, in which, phenolic compounds play a key role as antioxidants [2].

Alkaloids and their synthetic derivatives can be utilized for their analgesic and antispasmodic effects [3]. Natural antioxidants act as free-radical scavengers, chain breakers, complexes of pro-oxidant metal ions, and quenchers of singlet oxygen formation such as reactive oxygen species (ROS), which may damage cellular components of DNA, proteins, and lipids [4]. Flavonoid is reported to act as an antioxidants, which are scavengers of a wide range of ROS and also have inhibitors of lipid peroxidation [5].

Embelia ribes Burm F., belongs to family Primulaceae, is a woody liana found in the semi-evergreen to evergreen forest of India and is reported to be red-listed species [6]. The fruits are used as an anthelmintic, diuretic, carminative, contraceptive, antibacterial, antiinflammatory, and anti-astringent as reported in various literatures [7]. Conventionally, the seeds are employed as a remedy for toothache, headache, and snakebite. The seeds are mainly used for maintaining healthy skin and to support the digestive function. It is also effective in the treatment of fevers and for the diseases of chest [8]. Embelin is the principle chemical compound present in the berries of E. ribes. The other chemical constituents isolated from the seeds are quercitol, tannin, christembine, vilangin, resinoid, and volatile oil $[9,10]$. Hence, taking into consideration the importance of $E$. ribes, the study was carried out to investigate the fluorescence analysis, along with phytochemicals and antioxidant potential of aqueous and various solvent extracts of leaves and stem using the spectrophotometric method.

\section{MATERIALS AND METHODS}

Materials

All the chemicals used in the present study including standards were purchased from the Sigma-Aldrich; Himedia.

\section{Collection of the samples}

The leaves and stem of $E$. ribes were collected from Nagavalli, Karnataka $\left(14^{\circ} 02.973^{\prime} \mathrm{N}, 074^{\circ} 43.201^{\prime} \mathrm{E}\right)$. The voucher specimen was deposited at the Herbaria, Shivaji University, Kolhapur (Accession No: VVK01).

\section{Sample preparation for fluorescence analysis}

Powdered drug of different parts of plant gave different fluorescence under ultraviolet (UV) radiation. Each fluorescence characteristic of the treated sample was observed under visible light and then under UV light of both long and short wavelengths [11]. Therefore, fluorescence evaluation is used for the identification of plant and powdered drug [12]. Some crude drugs are often assessed qualitatively in this way, and it is an important parameter of pharmacognostic evaluation $[13,14]$.

The leaves and stem of E. ribes were dried in the shade to prevent decomposition of active principle and make fine powder for the fluorescence study. A small quantity (1 gm) of dried and finely powdered leaves and stem of $E$. ribes was treated with freshly prepared acids, alkaline solutions, and different solvents. The drug powders were treated with acids $\left(10 \% \mathrm{HCl}\right.$, Conc. $\mathrm{HCl}$, Conc. $\mathrm{H}_{2} \mathrm{SO}_{4}$, and Conc. $\left.\mathrm{HNO}_{3}\right)$, alkaline solutions ( $1 \mathrm{~N}$ aqueous $\mathrm{NaOH}, 1 \mathrm{~N}$ alcoholic $\mathrm{NaOH}$, and $5 \%$ 
$\mathrm{KOH}$ ), other chemicals ( $5 \%$ iodine, $5 \% \mathrm{FeCl}_{3}$, and acetone), and distilled water. They were subjected to study the fluorescence analysis in visible light and in short UV light (254 nm) and long UV light (365 nm).

\section{Preparation of extract for phytochemical studies}

Leaves and stem powder of E. ribes were extracted with $80 \%$ of methanol, ethanol, petroleum ether, and distilled water. Each sample $(1 \mathrm{~g})$ was extracted in $10 \mathrm{ml}$ of each solvent separately by continuous shaking on an orbital shaker for $9 \mathrm{~h}$ at $110 \pm 2 \mathrm{rpm}$ at controlled temperature $\left(30 \pm 1^{\circ} \mathrm{C}\right)$. The extracts were then filtered through Whatman filter paper No. 1 and stored in air tight vials in a refrigerator.

\section{Determination of total alkaloid content (TAC)}

TAC of leaves and stem extracts of E. ribes was measured using 1, 10-phenanthroline method [15]. A volume of $100 \mu \mathrm{l}$ of plant extract was mixed with $1 \mathrm{ml}$ of $0.05 \mathrm{M}$ of 1,10 -phenanthroline in ethanol and $1 \mathrm{ml}$ of $0.025 \mathrm{M} \mathrm{FeCl}_{3}$ in $0.5 \mathrm{M} \mathrm{HCL}$, and volume was adjusted to $10 \mathrm{ml}$ by adding distilled water. The reaction mixture was incubated for $30 \mathrm{~min}$ in water bath maintained at $70^{\circ} \mathrm{C}$. Above reaction mixture excluding plant extract, substituted by distilled water served as a blank. The absorbance was measured at $510 \mathrm{~nm}$ against reagent blank. The concentration of TAC was determined by milligrams colchicine equivalent per gram of dry weight by using calibration curve obtained from colchicine $(\mathrm{mg} / \mathrm{ml})$ standard solution [Fig. 1c]. All the samples measurements were performed in triplicates.

\section{Determination of total phenolic content (TPC)}

The determination of TPC of the various solvent extracts of leaves and stem of $E$. ribes was performed using Folin-Ciocalteu assay with some modification [16]. In brief, $125 \mu \mathrm{l}$ of extract was mixed with $1.8 \mathrm{ml}$ of Folin-Ciocalteu reagent and kept for $5 \mathrm{~min}$ at $25^{\circ} \mathrm{C}$. After this, $1.2 \mathrm{ml}$ of $15 \% \mathrm{Na}_{2} \mathrm{CO}_{3}$ was added to the reaction mixture and kept for $90 \mathrm{~min}$ at room temperature. The absorbance of the reaction was measured at $765 \mathrm{~nm}$. The concentration of the TPC was determined as milligrams of gallic acid equivalents per gram dry weight (mg GAE/g DW) using an equation obtained from gallic acid calibration curve [Fig. 1a]. All the samples estimation was performed in triplicates.

\section{Determination of total flavonoid content (TFC)}

TFC of various plant extracts of leaves and stem of E. ribes was quantified using the aluminum chloride colorimetric method [17]. The each solvent extract $(0.5 \mathrm{ml})$ was mixed with $1.5 \mathrm{ml}$ methanol, $0.1 \mathrm{ml}$ of $10 \%$ aluminium chloride, $0.1 \mathrm{ml}$ of $1 \mathrm{M}$ potassium acetate, and $2.8 \mathrm{ml}$ of distilled water. The mixture was vortexed, and the reaction was kept at the room temperature for 30 min and absorbance of reaction mixture was measured at $415 \mathrm{~nm}$. The concentration of the TFC was determined as milligram of rutin equivalent per gram dry weight ( $\mathrm{mg}$ $\mathrm{RE} / \mathrm{g}$ DW) using the calibration curve obtained from rutin $(\mathrm{mg} / \mathrm{ml})$ standard solution [Fig. 1b]. Estimation of all the samples was carried out in triplicate.

\section{Determination of antioxidant activity}

The antioxidant activity was performed using 1,1-diphenyl-2picrylhydrazyl (DPPH) and ferric reducing ability (FRAP) systems.

\section{Free-radical scavenging assay (DPPH)}

The DPPH radical scavenging activity of the various extracts of leaves and stem of E. ribes was estimated using modified and stable DPPH assay [18]. Stock reagent solution was prepared by dissolving $2.5 \mathrm{mg}$ of DPPH in $100 \mathrm{ml}$ of chilled methanol. A volume of $100 \mu$ l extract was allowed to react with $3 \mathrm{ml}$ of DPPH solution. The reaction mixture was vortex and kept in the dark at room temperature for $30 \mathrm{~min}$, and absorbance was recorded at $517 \mathrm{~nm}$. A control sample with no added extract was also analyzed, and the results were expressed as percent inhibition/radical scavenging activity (\%RSA) and calculated using the following formula:

$\operatorname{RSA}(\%)=[$ A control - A sample $/ \mathrm{A}$ control $] \times 100$

where, $\mathrm{A}=$ absorbance at $517 \mathrm{~nm}$.

\section{Ferric reducing antioxidant power (FRAP) activity}

The FRAP assay of various solvent extract of leaves and stem of $E$. ribes was carried out according to the described method by Benzie and Strain, 1996 with some modifications [19]. FRAP reagent formed by assimilation of the acetate buffer (0.3M - pH-3.6), 2, 4, 6- tripyridyl-s-triazine (TPTZ, $10 \mathrm{mM})$ ) in $40 \mathrm{mM} \mathrm{HCL}$, and $\mathrm{FeCl}_{3} .6 \mathrm{H}_{2} \mathrm{O}(20 \mathrm{mM})$ in 10:1:1 ratio former to use and heated to $37^{\circ} \mathrm{C}$ in water bath for $10 \mathrm{~min}$. The plant extracts of various concentrations were allowed to react with $2.7 \mathrm{ml}$ of the FRAP reagent, and the final volume of the reaction was adjusted to $3 \mathrm{ml}$ with distilled water; the reaction mixture was kept in dark for $30 \mathrm{~min}$, and the absorbance was recorded at $593 \mathrm{~nm}$. The results were expressed as $\mathrm{FeSO}_{4}$ equivalent antioxidant capacity [Fig. 1d].

\section{Statistical analysis}

The experiments were done in triplicates. Results were expressed as mean \pm standard deviation using Excel.
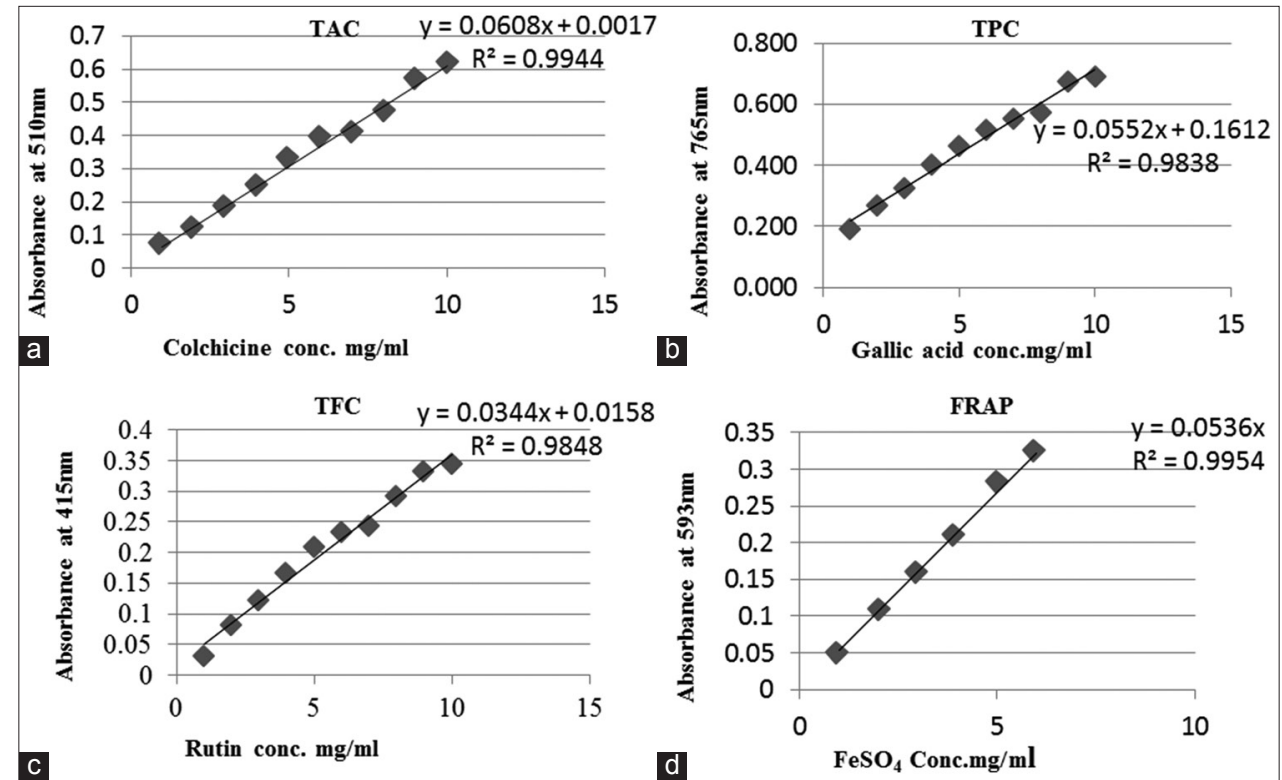

Fig. 1: Calibration curve of (a) Standard Colchicine, (b) Standard Gallic acid, (c) Standard Rutin, (d) Standard FeSO 


\section{RESULTS}

\section{Fluorescence analysis}

The fluorescence study of leaves and stem powder of E. ribes was treated with different chemical reagents and was observed under visible light and UV light (254 $\mathrm{nm}$ and $366 \mathrm{~nm}$ ), which shown predominantly fluorescence effect in both leaves as well as stem. Among the various chemical treatments, the leaves and stem powder of $E$. ribes showed the characteristic fluorescent green color when treated with $1 \mathrm{~N} \mathrm{NaOH}, 10 \% \mathrm{HCL}$, Conc. $\mathrm{HCl}$, Conc. $\mathrm{HNO}_{3}$, Conc. $\mathrm{H}_{2} \mathrm{SO}_{4}$, $5 \%$ iodine, $5 \% \mathrm{KOH}, 5 \% \mathrm{FeCl}_{3}$ acetone, and distilled water under short UV light [Tables 1 and 2]

\section{Phytochemical analysis}

Total alkaloid content (TAC)

The amount of TAC determined in different solvent extracts of leaves and stem of E. ribes [Table 3] showed the methanolic extract of leaves has highest TAC, that is, $19.05 \pm 0.42 \mathrm{mg} \mathrm{CE} / \mathrm{g} \mathrm{DW}$, followed by ethanolic extract with $14.59 \pm 0.11 \mathrm{mg} \mathrm{CE} / \mathrm{g}$ DW.
The petroleum ether extract of leaves has shown $13.38 \pm 1.10 \mathrm{mg} \mathrm{CE} / \mathrm{g}$ DW of TAC, and water extract has shown $9.94 \pm 2.86 \mathrm{mg} \mathrm{CE} / \mathrm{g}$ DW of TAC. The methanolic extract of stem has shown $11.60 \pm 2.86 \mathrm{mg} \mathrm{CE} / \mathrm{g}$ DW of TAC, followed by $10.88 \pm 0.41 \mathrm{mg} \mathrm{CE} / \mathrm{g}$ DW of TAC in ethanolic extract. The petroleum ether extract has shown $8.10 \pm 0.58 \mathrm{mg} \mathrm{CE} / \mathrm{g}$ DW of TAC, and water extract has shown $7.37 \pm 4.97 \mathrm{mg} C E / \mathrm{g}$ DW of TAC. From the present study, it is found that the TAC is higher in methanolic extract of leaves as compared to the stem of $E$. ribes.

TPC

The amount of TPC determined in different solvent extracts of leaves and stem of $E$. ribes [Table 3] reveals that the methanolic extract of stem shown the highest TPC, that is, $59.82 \pm 2.98 \mathrm{mg} \mathrm{GAE} / \mathrm{g} \mathrm{DW}$, followed by ethanolic extract with $44.65 \pm 3.35 \mathrm{mg} \mathrm{GAE} / \mathrm{g} \mathrm{DW}$.

The water extract of stem has shown the $30.44 \pm 1.43 \mathrm{mg} \mathrm{GAE} / \mathrm{g} \mathrm{DW}$ of TPC, and petroleum ether extract reported least $14.39 \pm 0.52 \mathrm{mg} \mathrm{GAE} / \mathrm{g}$ DW of TPC. The methanolic extract of leaves has shown the $55.27 \pm 1.29 \mathrm{mg}$ GAE/g DW of TPC, followed by ethanol with $32.23 \pm 1.29 \mathrm{mg}$ GAE/g

Table 1: Fluorescence study with different chemical reagents in visible and UV light of $E$. ribes stem powder

\begin{tabular}{|c|c|c|c|c|}
\hline S. No. & Stem powder+Reagent & Visible & Short wavelength & Long wavelength \\
\hline 1 & Powder as such & Tawny brown & Peanut & Caramel brown \\
\hline 2 & Powder+distilled water & Gingerbread brown & Pear green & Caramel brown \\
\hline 3 & Powder $+1 \mathrm{~N} \mathrm{NaOH}$ in distilled water & Brunette brown & Pine green & Black \\
\hline 4 & Powder $+1 \mathrm{~N} \mathrm{NaOH}$ in alcohol & Chocolate brown & Brunette brown & Black \\
\hline 5 & Powder $+10 \% \mathrm{HCl}$ & Caramel brown & Pear green & Brunette brown \\
\hline 6 & Powder+Conc. $\mathrm{HCl}$ & Syrup brown & Moss green & Black \\
\hline 7 & Powder+Conc. $\mathrm{HNO}_{3}$ & Walnut brown & Moss green & Gingerbread brown \\
\hline 9 & Powder+Acetone & Rust brown & Pickle green & Caramel brown \\
\hline 10 & Powder $+5 \%$ iodine & Amber brown & Juniper green & Black \\
\hline 11 & Powder+5\% KoH & Chocolate brown & Juniper green & Black \\
\hline 12 & Powder $+5 \% \mathrm{FeCl}_{3}$ & Mocha brown & Juniper green & Brown \\
\hline
\end{tabular}

Table 2: Fluorescence study with different chemical reagents in visible and UV light of E. ribes leaves powder

\begin{tabular}{llll}
\hline S. No. & Leaves powder+Reagent & Visible & Short wavelength \\
\hline 1 & Powder as such & Moss green & Olive green \\
2 & Powder+distilled water & Coffee & Seaweed green \\
3 & Powder+1 N NaOH in distilled water & Brown & Wood green \\
4 & Powder+1 $\mathrm{N} \mathrm{NaOH} \mathrm{in} \mathrm{alcohol}$ & Brown & Brown \\
5 & Powder+10\% HCl & Peanut brown & Black \\
6 & Powder+Conc. HCl & Coffee & Black \\
7 & Powder+Conc. $\mathrm{HNO}_{3}$ & Caramel brown & Hickory brown \\
8 & Powder+Conc. $\mathrm{H}_{2} \mathrm{So}_{4}$ & Chocolatebrown & Wood Brown \\
9 & Powder+Acetone & Coffee & Black \\
10 & Powder+5\% iodine & Walnut brown & Carob brown \\
11 & Powder+5\% KoH & Caramel brown & Juniper green \\
12 & Powder $+5 \% \mathrm{FeCl}_{3}$ & Brunette & Moss green \\
\hline
\end{tabular}

UV: Ultraviolet

Table 3: Averages of total alkaloid (mg CE $\left.\mathrm{g}^{-1} \mathrm{DW}\right)$, total phenolic (mg GAE $\left.\mathrm{g}^{-1} \mathrm{DW}\right)$, and flavonoid (mg RE $\mathrm{g}^{-1} \mathrm{DW}$ ) in different solvent extracts of Embelia ribes leaves and stem

\begin{tabular}{|c|c|c|c|c|c|}
\hline S. No. & Plant part & Solvent & $\begin{array}{l}\text { TAC } \\
\text { mg CE/g DW }\end{array}$ & $\begin{array}{l}\text { TPC } \\
\text { mg GAE/g DW }\end{array}$ & $\begin{array}{l}\text { TFC } \\
\text { mg RE/g DW }\end{array}$ \\
\hline 1 & & Methanol & $19.05 \pm 0.42$ & $55.27 \pm 1.29$ & $7.23 \pm 2.47$ \\
\hline 2 & Leaves & Ethanol & $14.59 \pm 0.11$ & $32.23 \pm 1.29$ & $9.33 \pm 2.94$ \\
\hline 3 & & Petroleum ether & $13.38 \pm 1.10$ & $9.69 \pm 3.02$ & $4.78 \pm 1.32$ \\
\hline 4 & & Water & $9.94 \pm 2.86$ & $20.55 \pm 0.60$ & $3.37 \pm 0.08$ \\
\hline 5 & & Methanol & $11.60 \pm 2.86$ & $59.82 \pm 2.98$ & $8.15 \pm 0.12$ \\
\hline 6 & Stem & Ethanol & $10.88 \pm 0.41$ & $44.65 \pm 3.35$ & $10.05 \pm 0.35$ \\
\hline 8 & & Water & $7.37 \pm 4.97$ & $30.44 \pm 1.43$ & $3.62 \pm 1.79$ \\
\hline
\end{tabular}

TAC: Total alkaloid content, TPC: Total phenolic content, TFC: Total flavonoid content 
DW of TPC. The water extract of leaves has shown the $20.55 \pm 0.60 \mathrm{mg}$ GAE/g DW of TPC, and petroleum ether extract has shown $9.69 \pm 3.02 \mathrm{mg}$ GAE/g DW of TPC. From the present study, the TPC found to be higher in methanolic extract of stem as compared to leaves of E. ribes.

TFC

The amount of TFC was determined in different solvent extracts of leaves and stem of $E$. ribes [Table 3] reveals that the ethanolic extract of stem has shown the highest TFC with $10.05 \pm 0.35 \mathrm{mg} \mathrm{RE} / \mathrm{g} \mathrm{DW}$, followed by methanolic extract with $8.15 \pm 0.12 \mathrm{mg} \mathrm{RE} / \mathrm{g}$ DW. The petroleum ether extract of stem has shown TFC with $5.84 \pm 0.24 \mathrm{mg} \mathrm{RE} / \mathrm{g} \mathrm{DW}$, followed by water with $3.62 \pm 1.7924 \mathrm{mg} \mathrm{RE} / \mathrm{g}$ DW. The ethanolic extract of leaves has shown $9.33 \pm 2.94 \mathrm{mg}$ RE/g DW of TFC, followed by methanolic extract with $7.23 \pm 2.47 \mathrm{mg} \mathrm{RE} / \mathrm{g}$ DW. The petroleum ether extract of leaves has shown $4.78 \pm 1.32 \mathrm{mg} \mathrm{RE} / \mathrm{g}$ DW of TFC, followed by water extract with $3.37 \pm 0.08 \mathrm{mg}$ RE/g DW. From the present study, the TFC found to be higher in ethanolic extract of stem as compared to the leaves of $E$. ribes.

\section{ANTIOXIDANT ACTIVITY}

\section{Free-radical scavenging assay (DPPH)}

DPPH free-radical scavenging activities of different solvent extracts of E. ribes leaves and stems [Table 4] reveal that ethanolic extract of stem exhibited higher DPPH radical scavenging activity, that is, $84.86 \pm 0.11 \%$, followed by methanolic extract with $77.19 \pm 0.13 \%$ inhibition. The petroleum ether extract of stem exhibited $35.55 \pm 1.78 \%$ inhibition, and the lowest DPPH radical scavenging activity $21.80 \pm 0.55 \%$ is shown by aqueous extract. The ethanolic extract of leaves has shown $79.81 \pm 0.15 \%$ DPPH radical scavenging activity, followed by methanolic extract with $71.15 \pm 0.14 \%$ inhibition. The petroleum ether extract of leaves exhibited $19.82 \pm 1.58 \%$ inhibition, and the lowest DPPH radical scavenging activity $18.43 \pm 0.98 \%$ is shown by aqueous extract. From the present study, it is found that the DPPH radical scavenging activity is higher in ethanolic extract of stem as compared to the leaves of $E$. ribes.

\section{Ferric reducing antioxidant power activity (FRAP)}

FRAP free-radical scavenging activities of different solvent extracts of E. ribes leaves and stem [Table 4] reported highest amount of FRAP activity in the methanolic extract of stem with $72.22 \pm 0.31 \mathrm{mg} \mathrm{Fe}^{+2} / \mathrm{g}$, followed by ethanolic extract with $65.05 \pm 0.26 \mathrm{mg} \mathrm{Fe}^{+2} / \mathrm{g}$ activity. The aqueous extract of stem has shown $36.89 \pm 0.62 \mathrm{mg} \mathrm{Fe}^{+2} / \mathrm{g}$ FRAP activity and the lowest FRAP activity, that is, $17.50 \pm 0.10 \mathrm{mg} \mathrm{Fe} / 2 / g$ is exhibited by petroleum ether extract of stem. The methanolic extract of leaves has shown $66.66 \pm 0.27 \mathrm{mg}$ $\mathrm{Fe}^{+2} / \mathrm{g}$ of FRAP activity, followed by ethanolic extract with $64.91 \pm 0.36 \mathrm{mg}$ $\mathrm{Fe}^{+2} / \mathrm{g}$. The aqueous extract of leaves has shown $39.27 \pm 1.26 \mathrm{mg} \mathrm{Fe}^{+2} / \mathrm{g}$ of FRAP activity. The lowest FRAP activity with $14.95 \pm 0.69 \mathrm{mg} \mathrm{Fe}^{+2} / \mathrm{g}$ is exhibited by petroleum ether extract of leaves. From the present study, it is found that the FRAP free-radical scavenging activity is higher in methanolic extract of stem as compared to the leaves of $E$. ribes.

\section{DISCUSSION}

Fluorescence analysis is an efficient, responsive, and precise method for the determination of various components in short period of time

Table 4: Averages of antioxidant assay DPPH (\% inhibition) and FRAP $\left(\mathrm{mgFe}^{-1} \mathrm{~g}^{-1} \mathrm{DW}\right)$ in different solvent extracts of Embelia ribes leaves and stem

\begin{tabular}{lllll}
\hline S. No. & $\begin{array}{l}\text { Plant } \\
\text { part }\end{array}$ & Solvent & $\begin{array}{l}\text { DPPH } \\
\text { \% inhibition }\end{array}$ & $\begin{array}{l}\text { FRAP } \\
\text { mgFe+2/g }\end{array}$ \\
\hline 1 & Leaves & Methanol & $71.15 \pm 0.14$ & $66.66 \pm 0.27$ \\
2 & & Ethanol & $79.81 \pm 0.15$ & $64.91 \pm 0.36$ \\
3 & & Petroleum ether & $19.82 \pm 1.58$ & $14.95 \pm 0.69$ \\
4 & & Water & $18.43 \pm 0.98$ & $39.27 \pm 1.26$ \\
5 & Stem & Methanol & $77.19 \pm 0.13$ & $72.22 \pm 0.31$ \\
6 & & Ethanol & $84.86 \pm 0.11$ & $65.05 \pm 0.26$ \\
7 & & Petroleum ether & $35.55 \pm 1.78$ & $17.50 \pm 0.10$ \\
8 & & Water & $21.80 \pm 0.55$ & $36.89 \pm 0.62$ \\
\hline
\end{tabular}

compared to several time-consuming dilutions steps involved in the analysis of pharmaceutical samples [20,21]. The fluorescence color shows specificity for each compound. The various plant materials show different coloration when subjected to different chemical reagents. It acts as a preliminary pharmacognostic parameter for identification and standardization of a particular drug from its adulterants. At varied wavelength, crude powder of plants shows diverse fluorescence due to the presence of different chemical constituents in the drug [14,22].

A correlation is found between a compound present in the drugs and their fluorescent behavior under different conditions. Under short UV radiation coumarin, especially hydroxyl amino acid derivative such as o-Coumaric acid appears yellowish green in alkaline condition. Flavonones which appear to be light yellow in aqueous condition, but under UV light, it appears to be bright yellow under alkaline conditions. Phytosterols when treated with $50 \% \mathrm{H}_{2} \mathrm{SO}_{4}$ appear to be green under UV light. Sapogenin and terpenoids show yellow green fluorescence under short UV light [23]. Quinine, aconitin, berberin, and emetin show specific colors of fluorescence. Least fluorescence is shown by fixed oils and fats [11]. In the present study, the major bioactive compounds present in the crude drug of $E$. ribes leaves and stem were found to be phenols, flavonoids, tannins, alkaloids, steroids, and quinine.

Alkaloids are utilized as stimulants, narcotics, pharmaceuticals, and poisons. At present, they are used in clinical treatments such as antimalarial quinine, the anesthetic cocaine, the stimulant caffeine and nicotine, the analgesics morphine and codeine, the gout suppressant colchicine, the antibiotic sanguinarine, the antiarrhythmic ajmaline, the anticancer vinblastine, taxol, and certain sedative $[24,25]$. Here, we are reporting the TAC from leaves and stem of E. ribes using different solvent extracts. Similar result for TAC in different plant parts of Chinchona officinalis has been reported [26].

Phenolic compound enhances the quality of plant by helping in plant growth and reproduction; they are produced in the plant as a response to environmental factors such as pollution, light, and irradiation [27]. From the leaves exact of $E$. ribes, $57.89 \pm 2.94 \mathrm{mg} \mathrm{GAE} / \mathrm{g}$ dry basis TPC was reported [28], whereas bark reported $26.59 \mathrm{mg}$ GAE/100g of TPC [29].

In the present study, it was noticed that TPC content was higher in stem as compared to leaves in E. ribes. Flavonoid is a polyphenolic secondary metabolite which helps in pollination, as a repellent to pest, responsible for pigmentation of various parts of plant and in nodule formation [30-32]. It has potential antioxidant property [33]. From the bark extract of E. ribes, $01.35 \mathrm{mg} \mathrm{QE} / 100 \mathrm{~g}$ was reported [29]. Since no data are available for TFC in leaves and stem of E. ribes, from the present study, we are reporting the TPC and TFC contents in stem are found to be higher than leaves. Similar kind of work done using different solvent extraction is carried out in P. minima Linn and Eclipta prostrata (L.) L $[34,35]$

Antioxidant, molecules act as protector against free-radical damage. They have shown a major contribution to the prevention of many chronic diseases such as cancer, cardiovascular disease, hepatitis, asthma, atherosclerosis, arthritis, and diabetes [36-38]. Since some plant extracts show complication, use of different methods is recommended for the evaluation of antioxidant activity [32]. In the present study, we have used DPPH and FRAP antioxidant assays for leaves and stem of E. ribes. FRAP activity of $60.75 \pm 0.16 \mathrm{mg}$ Asc AE/g dry basis was reported in the leaves of $E$. ribes [28]. It seems no data are available for the DPPH and FRAP free-radical scavenging activities on the stem of $E$. ribes. It was observed that antioxidant activity in stem is higher than that of leaves. There is influence of different solvents on the extraction of plant material. Similar kind of results are reported from wheat and Salacia chinensis L [38,39]. Antioxidant activity was observed in the phenolic extract from Russula laurocerasi with the similar kind of result [40]. DPPH free-radical scavenging assay was used to observed antioxidant activity in various solvent extract of sweet orange peel and makrut lime [41,42]. 


\section{CONCLUSION}

From the present study, it can be concluded that leaves and stem of E. ribes show the presence of different bioactive compounds in the fluorescence analysis, which might be ideal for various pharmaceutical applications. It is clearly indicated from the present study that polarity of solvent plays a major role in extraction of phytoconstituents. Among the four solvents used for extraction, methanolic extract of stem was found to be the superior compared to ethanolic, water, and petroleum ether extracts with respect to TAC, TPC, and FRAP. Ethanolic extract of stem found to be superior for TFC and DPPH activities. The leaves and stem of E. ribes are good source of antioxidants and secondary metabolite, which can be used for the various pharmaceutical applications.

\section{ACKNOWLEDGMENT}

The authors are thankful to the Head, Department of Botany, Shivaji University, Kolhapur, for providing the necessary facilities. VVK is thankful to UGC, New Delhi, for financial support under UGC-BSR Fellowship in Sciences for Students (No.F.25-1/2013-14 (BSR)/7163/2007(BSR)).

\section{AUTHORS' CONTRIBUTIONS}

Vidya Kamble has performed all the experiments in the laboratory of Cytogenetics and Plant Breeding, Department of Botany, Shivaji University, Kolhapur. Dr. Nikhil Gaikwad has given the experimental design, intellectual content for the selection of plant and is the mentor of the present work.

\section{CONFLICTS OF INTEREST}

The authors are declaring that there are no conflicts of interest regarding the publication of this research article.

\section{REFERENCES}

1. Khatua S, Roy T, Acharya K. Antioxidant and free radical scavenging capacity of phenolic extract from Russula laurocerasi. Asian J Pharm Clin Res 2013;6:156-60.

2. Olajuyigbe OO, Afolayan AJ. Pharmacological assessment of the medicinal potential of Acacia mearnsii de wild.: Antimicrobial and toxicity activities. Int J Mol Sci 2012;13:4255-67.

3. Ahmad N, Abbasi BH, Rahman IU, Fazal H. Piper nigrum: Micropropagation, antioxidative enzyme activities, and chromatographic fingerprint analysis for quality control. Appl Biochem Biotechnol 2013;169:2004-15.

4. Chang CY, Wen HM, Chern J. Estimation of total flavonoid content in propolis by two complementary colorimetric methods. J Food Drug Anal 2002; 10:178-82.

5. Sulaiman CT, Balachandran I. Total phenolics and total flavonoids in selected Indian medicinal plants. Indian J Pharm Sci 2012;74:258-60.

6. Abbasi BH, Stiles AR, Saxena PK, Liu CZ. Gibberellic acid increases secondary metabolite production in Echinacea purpurea hairy roots. Appl Biochem Biotechnol 2012;168:2057-66.

7. Seth SD, Johri N, Sundaram KR. Antispermatogenic effect of embelin from Embelia ribes. Indian J Pharmacol 1982;14:207-11.

8. Gupta OP, Ali MM, Ray GB. Some pharmacological investigations of embelin and its semisynthetic derivatives. Indian J Physiol Pharmacol 1977;21:31-9.

9. Reddy M, Chaturvedi A. Pharmacognostical studies of Hymenodictyon orixence (Roxb.) Mabb. Leaf. Int J Ayurveda Res 2010;1:103-5.

10. Pimenta AM, Montenegro MC, Ujo AN, Mart'inez JC. Application of sequential injections analysis to pharmaceutical analysis. J Pharm Biomed Anal 2006;40:16-34.

11. Singh SP, Shukla S, Yadav HK. Multivariate analysis in relation to breeding system in opium poppy (Papaver somniferum L.). Genetika 2004;36:111-20.

12. Chakravarthy BK, Gupta S, Gambhir SS, Gode KD. Pancreatic $\beta$-cell regeneration-A novel antidiabetic mechanism of Pterocarpus marsupium Roxb. Indian J Pharmacol 1980;12:123-7.

13. Girthori JB, Hoglund J, Waller PJ, Baker R. Evaluation of antihelminthic properties of extracts from some plants used as livestocks dewormers by pastoralist and small holder farmers in Kenya against Heligmosomoides polygyrus infections in mice. Vet Parasite 2003;118:215-26.

14. Mol J, Grotewold E, Koes R. How genes paint flowers and seeds. Trends Plant Sci 1998;3:212-7.

15. Roberts MF, Wink M, editors. Alkaloids: Biochemistry, Ecology and Medicinal Applications. New York: Plenum Press; 1998. p. 327-36.

16. Martin WE, Gandara JA. Alkaloid content of Ecuadoran and other American Cinchona barks. Bot Gaz 1945;107:184-99.

17. Korkina LG, Afanas'ev IB. In: Sies H, editor. Antioxidants in Disease Mechanisms and Therapy. San Diego: Academic Press; 1997. p. 151-63.

18. Evans WC. Trease and Evans Pharmacognosy. Vol. 1. Singapore: Harcourt Baraco and Company Asia Pvt. Ltd.; 1996. p. 437-44.

19. Williams RJ, Spencer JP, Rice-Evans C. Flavonoids: Antioxidants or signalling molecules? Free Radic Biol Med 2004;36:838-49.

20. Singleton VL, Rossi JA. Colorimetry of total phenolics with phosphomolybdic phosphotungstic acid reagents. Am J Enol Vitic 1965;16:144-58

21. Lindley $\mathrm{M}$. The impact of food processing on antioxidants in vegetable oils, fruits and vegetables. Trends Food Sci Technol 1998;9:336-40.

22. Gupta MK, Sharma PK, Ansari SH, Lagarkha R. Pharmacognostical evaluation of Grewia asiatica fruits. Int J Plant Sci 2006;1:249-51.

23. Harborne JB. Functions of flavonoids in plants. In: Goodwin TW, editor. Chemistry and Biochemistry of Plant Pigments. New York: Academic Press; 1976. p. 736-78.

24. Balandrin MF, Kjocke AJ, Wurtele E. Natural plant chemicals: Sources of industrial and mechanical materials. Science 1985;228:1154-60.

25. Chavan JJ, Jagtap UB, Gaikwad NB, Dixit GB, Bapat VA. Total phenolics, flavonoids and antioxidant activity of Saptarangi (Salacia chinensis L.) fruit pulp. J Plant Biochem Biotechnol 2013;22:409-13.

26. John B, Sulaiman CT, George S, Reddy VR. Spectrophotometric estimation of total alkaloids in selected Justicia species. Int J Pharm Pharm Sci 2014;6:647-8.

27. Benzie IF, Strain JJ. Ferric reducing ability of plasma (FRAP) as a measure of antioxidant power: The FRAP assay. Anal Biochem 1996;239:70-6.

28. Jarald EE, Jarald SE. A Text Book of Pharmacognosy and Phytochemistry. $1^{\text {st }}$ ed. New Delhi, India: CBS Publishers and Distributors; 2007. p. 6.

29. Ansari MM, Ahmad J, Ansari SH. Pharmacognostic evaluation of the stem bark of Balanites aegyptica Delile "Hingot". Hamdard Med 2006;50:82-94.

30. Ravi KK, Ved DK. Illustrated Field Guide: 100 Red Listed Medicinal plants for Conservation Concern in Southern India. India: Foundation for Revitalization of Local Health Traditions, Bangalore; 2000. p. 467.

31. Middleton E, Kandaswamy C, Theoharides TC. The effects of plant flavonoids on mammalian cells: Implications for inflammation, heart disease, and cancer. Pharmacol Rev 2000;52:673-751.

32. Valentine IK, Maria VK, Bruno B. Phenolic cycle in plants and environment. J Mol Cell Biol 2003;2:13-8.

33. Sharma PC, Yelne MB, Dennis TJ. Database on Medicinal Plants used in Ayurveda and Siddha. New Delhi: Central Council for Research in Ayurveda and Siddha; 2002. p. 478-99.

34. Venkanna B, Uma A, Jayalakshmi L. In vitro total phenolics, flavonoids contents, antioxidant and antimicrobial activites of various solvent extracts from the medicinal plant Physalis minima Linn. Int J Pharm Pharm Sci 2017;9:192-8.

35. Shilpam S, Richa R. Phytochemical screening and antioxidant potential of Eclipta prostrata (L) L-a valuable herb. Int J Pharm Pharm Sci 2016;8:255-60.

36. Naraporn P, Varipat A. Screening for antioxidant activity in selected Thai wild plants. Asian J Food Agro Ind 2009;2:433-40

37. Jagtap UB, Panaskar SN, Bapat VA. Evaluation of antioxidant capacity and phenol content in Jackfruit (Artocarpus heterophyllus Lam.) fruit pulp. Plant Food Hum Nutr 2010;65:99-104.

38. Harisaranraj R, Suresh K, Saravanababu S. Evaluation of the chemical composition Rauwolfia serpentina and Ephedra vulgaris. Adv Biol Res 2009;3:174-8.

39. Harborne JB. Phytochemical Methods. New York: Chapman and Hall; 1976. p. 1-288.

40. Zhou K, Yu L. Antioxidant properties of bran extracts from trego wheat grown at different locations. J Agri Food Chem 2004;52:1112-7.

41. Fidrianny I, Harnovi M, Insanu M. Evaluation of antioxidant activities from various extracts of sweet orange peels using DPPH. Asian J Pharm Clin Res 2014;7:186-90.

42. Fidrianny I, Johan Y, Sukrasno. Antioxidant activities of different polarity extracts from three organs of makrut lime (Citrus hystrix DC) and correlation with total flavonoid, phenolic, carotenoid content. Asian J Pharm Clin Res 2015;8:239-43. 